\title{
Structural and vibrational characterisation of 3-amino-1-propanol a concerted SCF-MO ab initio, Raman and infrared (matrix isolation and liquid phase) spectroscopy study
}

\author{
Constança Cacela $^{\text {a, }}$ M.L. Duarte ${ }^{\text {a }}$, Rui Fausto ${ }^{\text {b,* }}$ \\ ${ }^{a}$ Departamento de Química e Bioquímica, CECUL, Faculdade de Ciências, Universidade de Lisboa, 1749-016 Lisbon, Portugal \\ b Departamento de Química, Universidade de Coimbra, P-3049 Coimbra, Portugal
}

Received 20 July 1999; accepted 31 August 1999

\begin{abstract}
Results obtained for the isolated and liquid 3-amino-1-propanol by a concerted molecular orbital and vibrational spectroscopic approach are reported. The relative energies and both structural and vibrational data of the different conformers of the studied compound were calculated using the extended $6-31 \mathrm{G}^{*}$ basis set both at the HF-SCF and MP2 ab initio levels of theory and the theoretical results used to interpret Raman and infrared experimental data. In the gaseous phase and for the molecule isolated in an Argon matrix, monomeric 3-amino-1-propanol exists as a mixture of conformers, the first and second lowest energy forms corresponding to conformers which exhibit an intramolecular $\mathrm{OH}-\mathrm{N}$ hydrogen bond (forms I and II). On the other hand, in the pure liquid, where intermolecular H-bonding occurs, the monomeric unit within the aggregates assumes a conformation similar to that of the third most stable form found for the isolated molecule situation (form III), which is characterised by having a weak intramolecular $\mathrm{NH}-\mathrm{O}$ bond. The experimental data obtained for the pure liquid also reveals the presence of monomeric form I in this phase, a result that is in consonance with the strongly stabilizing $\mathrm{OH}-\mathrm{N}$ intramolecular hydrogen bond that is present in this conformer. (C) 2000 Elsevier Science B.V. All rights reserved.
\end{abstract}

Keywords: 3-Amino-1-propanol; Intra and intermolecular hydrogen bonding; Infrared and Raman spectra; Matrix isolation; HF-SCF; MP2 6-31G* ab initio calculations

\footnotetext{
* Corresponding author. Tel.: + 351-39-22826; fax: + 35139-27703.

E-mail address: rfausto@gemini.ci.uc.pt (R. Fausto)
}

\section{Introduction}

The conformational isomerism in isolated and liquid 2-aminoethanol (2AE) has been recently investigated in our laboratory by a concerted molecular orbital and vibrational spectroscopic approach [1]. In the present study, results ob- 

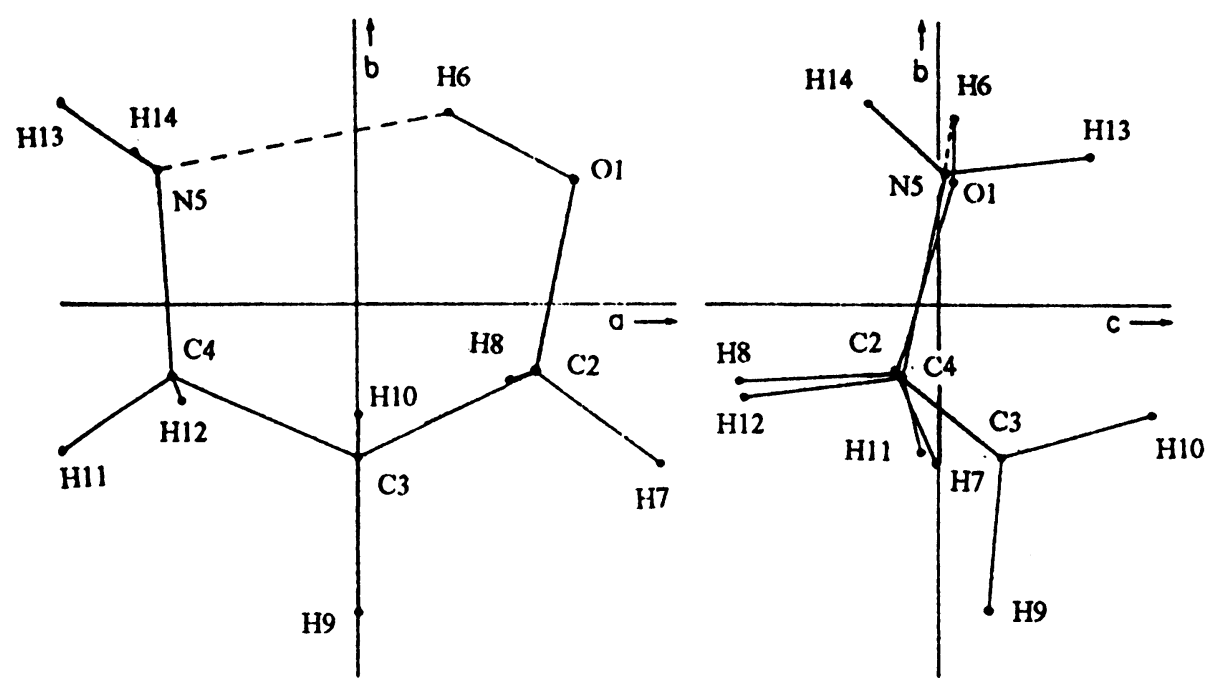

Fig. 1. Projections of the resulting structure of 3-amino-1-propanol obtained by microwave spectroscopy (adapted from [2]).

tained for the more complex aminoalcohol 3amino-1-propanol (3AP) using a similar methodology are reported.

From our previous studies in $2 \mathrm{AE}$, it could be established that the simultaneous presence in this molecule of the $\mathrm{NH}_{2}$ and $\mathrm{OH}$ groups allows the establishment of different types of intra and intermolecular hydrogen bonding which were found to have different importance in the various phases studied. For the isolated molecule, $\mathrm{OH}-\mathrm{N}$ and $\mathrm{NH}-\mathrm{O}$ intramolecular hydrogen bonding may occur, the first being considerably stronger than the last [1]. On the other hand, in the liquid phase, the intramolecular $\mathrm{NH}-\mathrm{O}$ hydrogen bonding plays a prominent role in stabilising the conformations that are the most populated forms under this condition, while the $\mathrm{OH}-\mathrm{N}$ intramolecular hydrogen bonding is virtually absent. This latter is replaced by the stronger $\mathrm{OH}-\mathrm{N}$ intermolecular hydrogen bonding that becomes the prevalent interaction in this phase [1]. In a similar way to that found in $2 \mathrm{AE}$, it can than be expected that, both in isolated and liquid 3AP, hydrogen bonding interactions are also the main factor leading to the stabilisation of certain conformations.

$3 \mathrm{AP}$ is characterised by four independent torsional angles (lp-N5-C4-C3, N5-C4-C3-C2, C4C3-C2-O1, C3-C2-O1-H6; lp, lone pair). The different stable conformations are obtained by rotation around the $\mathrm{C} 4 \mathrm{~N} 5, \mathrm{C} 3 \mathrm{C} 4, \mathrm{C} 2 \mathrm{C} 3$ and $\mathrm{O} 1 \mathrm{C} 2$ bonds, and the values of the appropriate dihedral angles are, in all cases, expected to be close to $60^{\circ},-60^{\circ}$ and $180^{\circ}$.

In a microwave study of $3 \mathrm{AP}$ [2] in the gaseous phase, a structure close to a gauche-gauchegauche-gauche form, with an $\mathrm{OH}-\mathrm{N}$ intramolecular hydrogen bond, was found to be the most stable conformer (Fig. 1). To simultaneously form the hydrogen bond and keep the internal rotation energy minimum, the molecule folded itself to a compact six-membered ring, the OCCCN framework being slightly distorted from the exactly staggered configuration towards planarity. A recent gas-phase infrared study supported the microwave results, clearly demonstrating that a conformer with an intramolecular $\mathrm{OH}-\mathrm{N}$ bond strongly predominates in this phase, while evidences of the presence of a second conformer with a free $\mathrm{OH}$ group were also presented [3].

Theoretical studies carried out at the HF 4-31G [4-6] and DFT B3lyp [3] levels have also established the importance of the intramolecular $\mathrm{OH}-\mathrm{N}$ interaction in this type of compounds. For $3 \mathrm{AP}$, these calculations indicate that this interaction is present in the two most stable conformations, despite in the second lowest energy form it is of minor importance. The intramolecular $\mathrm{NH}-\mathrm{O}$ interaction was considered to be present in 
four of the minima found in the potential energy surface of $3 \mathrm{AP}$, but it was suggested to be a weak interaction [3-6].

In an infrared spectroscopic study of aminoalcohols in solution [7] it was proposed that the presence in these compounds of strong intramolecular hydrogen bonding may reduce considerably their association tendency, so that a considerable amount of intramolecularly hydrogen-bonded species may exist in concentrated solutions. The associated species formed were largely composed of cyclic dimers, whose precise nature was found to depend on the strength of the intramolecular hydrogen bond. In 3AP, the dimers involved the participation of the nitrogen atom, so that fairly large ring dimers (twelvemembered), with an intermolecular $\mathrm{OH}-\mathrm{N}$ hydrogen bond, are formed [7].

As mentioned above, the prevalent hydrogen bonding in liquid $2 \mathrm{AE}$ is the intermolecular $\mathrm{OH}-\mathrm{N}$ bonding [1]. The formation of this bond, whose mean energy of stabilization is known to be ca. $29 \mathrm{~kJ} \mathrm{~mol}^{-1}$ [8] (i.e. nearly twice that associated with the intramolecular process in the most stable conformer [1,9]), leads necessarily to the break of the intramolecular $\mathrm{OH}-\mathrm{N}$ hydrogen bond of the two most stable forms found in the vapour phase. Indeed, no spectroscopic evidence of the presence of these two forms in liquid $2 \mathrm{AE}$ could be found [1]. The preferred conformations in the liquid phase are those which have an intramolecular $\mathrm{NH}-\mathrm{O}$ hydrogen bond, that was found to activate both the $\mathrm{OH}$ and $\mathrm{NH}_{2}$ groups to the establishment of the prevalent $\mathrm{OH}-\mathrm{N}$ intermolecular hydrogen bond. It could be expected that 3AP should show a similar behaviour. Nevertheless, since 3AP has an increased conformational flexibility (which shall lead to stronger intramolecular hydrogen bonding), its association tendency shall reduce when compared to $2 \mathrm{AE}$, and we would expect an increased amount of the free intramolecularly $\mathrm{OH}-\mathrm{N}$ hydrogen bonded species to be present in the pure liquid. Such hypothesis appeared attractive to investigation, since the relative amount of free versus associated species may play a dominant role in determining the ability of linear aminoalcohols to form very stable glasses that can be successfully used to prevent ice formation during the process of vitrification in organ or biological tissues cryopreservation [10]. In addition, to date, most of the theoretical studies on 3AP have focused only on the energies, structures and intramolecular interactions of the most stable conformations for the isolated molecule situation. The vibrational data is very scarce and have not yet been correlated with a high level theoretical model.

In this article, the vibrational spectra of $3 \mathrm{AP}$ in the liquid phase, in $\mathrm{CCl}_{4}$ solution and isolated in an Ar matrix are presented. These data are interpreted with the help of theoretical results obtained from vibrational calculations carried out using the $\mathrm{HF} / \mathrm{SCF}-\mathrm{MO}$ 6-31G* ab initio calculated force fields.

\section{Experimental}

3AP was obtained commercially spectroscopic grade (Aldrich, purity $99+\%$ ) and was used without any additional purification. The sample was handled in a glove box to avoid moisture from air. To undertake the matrix-isolation infrared studies the sample was pre-mixed with $\mathrm{Ar}$ (99,999\% purity) under reduced pressure. The gas mixture (matrix:solute $=1500$ ) thus formed was then sprayed onto the cold $\mathrm{KBr}$ window at $14 \mathrm{~K}$. The gas flux was controlled with two swagelok valves (models BMG and BMRG), which make the connection to an APD cryogenics DMX closed cycle helium refrigeration system whose principal component is a DE-202 Displex expander. The refrigeration system is supported by an APD cryogenics Helium compressor (model HC-2D-1). For the conventional IR spectra a specially designed demountable transmission variable temperature cell with $\mathrm{KBr}$ windows, linked to a T48 (Red Lion Controls) temperature controller was used. The IR spectra were obtained using a Mattson (Infinity Series) or a Bomem (MB104) Fourier Transformer spectrometer equipped with a deuterated triglycine sulphide (DTGS) detector and $\mathrm{Ge} / \mathrm{KBr}$ or $\mathrm{Zn} / \mathrm{Se}$ optics. Data collection was performed with $1 \mathrm{~cm}^{-1}$ spectral resolution. Solution studies were undertaken at room temperature using $\mathrm{CCl}_{4}$ (Riedel-de-Häen, 

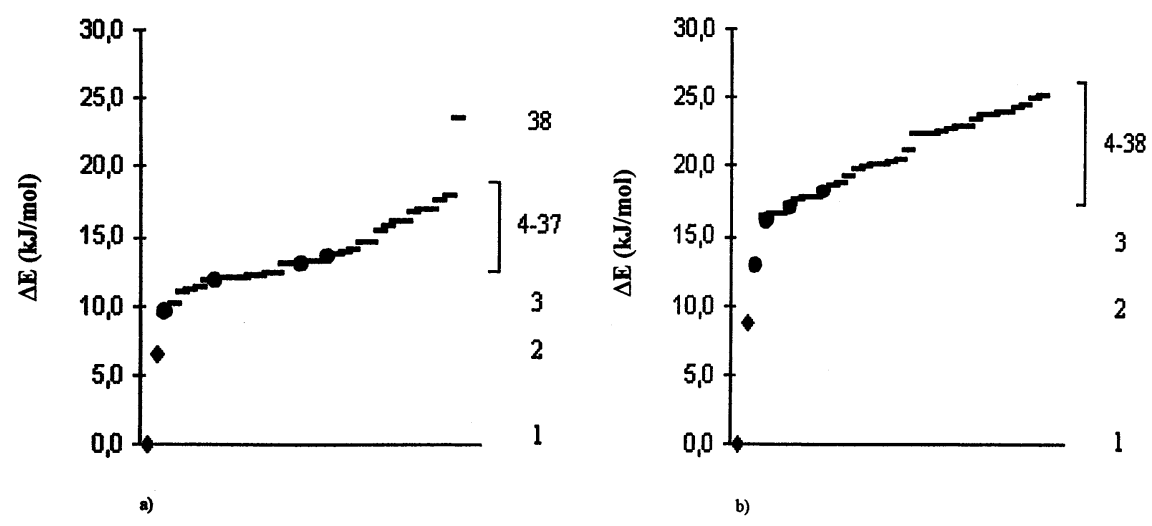

Fig. 2. Relative energies of the 38 local minima found in the a) HF and b) MP2 6-31G* potential energy surfaces of 3-amino-1-propanol with respect to the most stable structure. conformers with an $\mathrm{OH}-\mathrm{N}$ intramolecular hydrogen bond, conformers with an $\mathrm{NH}-\mathrm{O}$ intramolecular hydrogen bond.

spectroscopic grade) as solvent and covering a concentration range from $2.5 \times 10^{-3} \mathrm{M}$ to $5.0 \times$ $10^{-1} \mathrm{M}$.

Raman spectrum was obtained using a Spex 1403 double monochromator spectrometer (focal length $0.85 \mathrm{~m}$, aperture $f / 7.8$ ) equipped with holographic gratings with 1800 groove $/ \mathrm{mm}$ (reference 1800-1SHD). The $514.5 \mathrm{~nm} \mathrm{Ar}^{+}$laser, adjusted to provide $220 \mathrm{~mW}$ power at the sample, was used as excitation radiation. Detection was effected using a thermoelectrically cooled Hamamatsu R928 photomultiplier. The spectrum was recorded using increments of $1 \mathrm{~cm}^{-1}$ and integration times of $1 \mathrm{~s}$.

Band intensities, from the matrix-isolation and Raman spectra, were obtained from the area of the observed peaks, subjected to previous deconvolution by using the peak fitting module of ORIGIN 4.0 [11].

A simulation of the Ar matrix and calculated HF $6-31 G^{*}$ spectra of isolated 3AP was performed by gaussian synthesis, from the experimental and $a b$ initio frequencies and intensities, using the SYNSPEC programme [12].

The ab initio molecular orbital calculations were performed using the $6-31 \mathrm{G}^{*}$ basis set [13] with the GAUSSIAN92 program package [14] running on a DEC ALPHA 7000 computer. Molecular geometries were fully optimised by the force gradient method using Berny's algorithm [15] and the standard convergence criteria for the geometry optimisation both at the Hartree-Fock and MP2 levels of theory. The HF 6-31G* ab initio calculated vibrational spectra were then used to help interpretation of the spectroscopic results, the calculated wavenumbers being scaled down in order to fit to the experimental values by using a single scale factor $(0.89$ [16]). Normal co-ordinates analysis was undertaken using the programs TRANSFORMER, BUILD-G and VIBRAT [17] which are interfaced with GAUSSIAN92.

\section{Results and discussion}

Relative energies of the 38 local minima found in the HF and MP2 potential energy surface of 3AP are shown graphically in Fig. 2. The three most stable conformers of the studied molecule are depicted in Fig. 3, and some calculated relevant data for these forms (relative energies, predicted population at room temperature assuming a Boltzmann distribution and selected structural data) are compared with the available experimental data in Table $1^{1}$.

Considering the sum of Van der Waals radii of $(\mathrm{H}+\mathrm{N})=270 \mathrm{pm}$ and $(\mathrm{H}+\mathrm{O})=260 \mathrm{pm}$ [18], conformers I and II, with $\mathrm{r}(\mathrm{OH}-\mathrm{N})<270 \mathrm{pm}$, and conformer III, with $\mathrm{r}(\mathrm{NH}-\mathrm{O})<260 \mathrm{pm}$, are considered to be stabilised by an $\mathrm{OH}-\mathrm{N}$ or $\mathrm{NH}-\mathrm{O}$

\footnotetext{
${ }^{1}$ Complete structural and energetic data for all the minima may be obtained from the corresponding author upon request.
} 
intramolecular hydrogen bond, respectively, these interactions being the main factors responsible for their low energy.

From Fig. 2 it can be seen that there is a relatively large energy gap between the most stable form (I) and all the other conformers. This conformer is then predicted to be considerably more populated (MP2: 95.5\%; HF: $78.8 \%$ ) at room temperature than the remaining forms. The greater relative stability of this structure clearly shows that the intramolecular $\mathrm{OH}-\mathrm{N}$ hydrogen bond it exhibits is considerably strong. The 2 nd

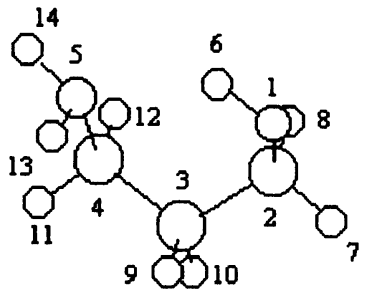

I

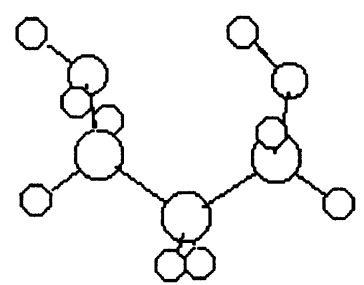

II

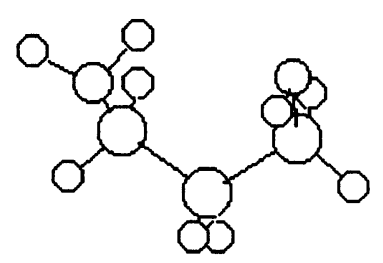

III

Fig. 3. Lowest energy conformers of 3-amino-1-propanol.

Table 1

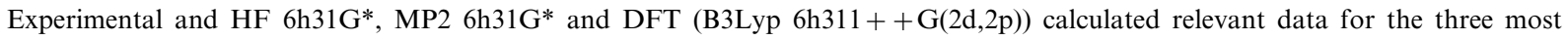
stable forms of 3-amino-1-propanol ${ }^{\mathrm{a}}$

\begin{tabular}{|c|c|c|c|c|c|c|c|c|}
\hline & \multicolumn{4}{|l|}{ Form I } & \multicolumn{2}{|l|}{ Form II } & \multicolumn{2}{|l|}{ Form III } \\
\hline & $\operatorname{Exp}^{b}$ & $\mathrm{DFT}^{\mathrm{c}}$ & $\mathrm{HF}$ & MP2 & $\mathrm{HF}$ & MP2 & $\mathrm{HF}$ & MP2 \\
\hline$\Delta \mathrm{E}$ & 0.00 & 0.00 & 0.00 & 0.00 & 6.57 & 8.82 & 9.55 & 12.77 \\
\hline $\mathrm{p}$ & & & 78.8 & 95.5 & 5.6 & 2.7 & 1.7 & 0.6 \\
\hline $\mathrm{p}_{\mathrm{i}} / \mathrm{p}_{\mathrm{I}}$ & & & 1 & 1 & 0.07 & 0.03 & 0.02 & 0.01 \\
\hline \multicolumn{9}{|l|}{ Bond length } \\
\hline $\mathrm{CO}$ & 143 & 142.1 & 139.7 & 142.1 & 139.9 & 142.3 & 140.1 & 143.3 \\
\hline $\mathrm{CN}$ & 148 & 147.8 & 146.3 & 147.6 & 146.0 & 147.3 & 145.5 & 146.8 \\
\hline $\mathrm{OH}$ & 97 & 97.0 & 95.2 & 98.1 & 94.9 & 97.8 & 94.8 & 97.4 \\
\hline $\mathrm{d}(\mathrm{OH}-\mathrm{N})$ & 208 & 204 & 212 & 197 & 245 & 219 & 296 & 278 \\
\hline $\mathrm{d}(\mathrm{NH}-\mathrm{O})$ & & & 313 & 306 & 367 & 353 & 233 & 224 \\
\hline \multicolumn{9}{|l|}{ Dihedral } \\
\hline $\mathrm{H} 13 \mathrm{~N} 5 \mathrm{C} 4 \mathrm{C} 3$ & -66.5 & -71.2 & -68.7 & -70.0 & -63.3 & -63.5 & 187.4 & 187.1 \\
\hline H14N5C4C3 & 173.5 & 170.5 & 173.1 & 173.7 & 178.5 & 180.4 & 68.7 & 70.6 \\
\hline $\mathrm{N} 5 \mathrm{C} 4 \mathrm{C} 3 \mathrm{C} 2$ & -68.9 & -61.9 & -60.5 & -59.0 & -45.3 & -43.0 & -71.7 & -70.6 \\
\hline $\mathrm{C} 4 \mathrm{C} 3 \mathrm{C} 2 \mathrm{O} 1$ & 76.6 & 67.7 & 70.2 & 69.4 & -44.4 & -40.9 & 59.9 & 58.1 \\
\hline $\mathrm{C} 3 \mathrm{C} 2 \mathrm{O} 1 \mathrm{H} 6$ & -42.0 & -45.9 & -52.8 & -51.9 & 73.2 & 70.4 & 56.5 & 50.9 \\
\hline \multicolumn{9}{|l|}{ Charge } \\
\hline $\mathrm{H} 6$ & & & 0.479 & 0.489 & 0.461 & 0.473 & 0.442 & 0.442 \\
\hline $\mathrm{N}$ & & & -0.877 & -0.881 & -0.870 & -0.876 & -0.862 & -0.862 \\
\hline
\end{tabular}

${ }^{a}$ Relative energies to the most stable conformer, $\Delta \mathrm{E}$, in $\mathrm{kJ} \mathrm{mol}^{-1}$; predicted populations, $\mathrm{p}(\%)$, at room temperature, were calculated assuming a Boltzmann distribution (the total population of the remaining 35 conformers is predicted as $\mathrm{p}<14 \%$ and $\mathrm{p}<2 \%$ at the HF and MP2 levels of theory, respectively); bond lengths and distances in pm; dihedral angles in degrees; Mülliken atomic charges in units of electron $\left(1 \mathrm{e}^{-}=-1.6 \times 10^{-19} \mathrm{C}\right)$.

${ }^{\mathrm{b}}$ From [2].

${ }^{\mathrm{c}}$ From [3]. 
lowest energy form, predicted to have an energy of $8.82 \mathrm{~kJ} \mathrm{~mol}^{-1}$ (HF: $6.57 \mathrm{~kJ} \mathrm{~mol}^{-1}$ ) above the most stable conformer, has also an $\mathrm{OH}-\mathrm{N}$ intramolecular H-bond, which is however considerably weaker than that present in the conformational ground state, as can be seen by comparing the distances between the atoms involved in this interaction in these two conformers (MP2: 197 pm versus 219 pm; HF: 212 pm versus $245 \mathrm{pm}$; see Table 1). The longer $\mathrm{CN}$ and $\mathrm{OH}$ bond distances, the larger absolute values for the atomic charges of $\mathrm{H} 6$ and $\mathrm{N}$ and the shorter $\mathrm{CO}$ bond length calculated for conformer I are also consistent with the existence in this form of a stronger H-bond interaction. On the other hand, form III, with an energy of ca. $12.77 \mathrm{~kJ} \mathrm{~mol}^{-1}$ (HF: $9.55 \mathrm{~kJ} \mathrm{~mol}^{-1}$ ) above the most stable conformer, exhibits the much weaker $\mathrm{NH}-\mathrm{O}$ intramolecular interaction. The calculations also predict the existence of three higher energy minima showing an intramolecular $\mathrm{NH}-\mathrm{O}$ hydrogen bond (see Fig. 2).

It is worth to mention that the relative energies of the three lowest energy conformers calculated using the $6-31 \mathrm{G}^{*}$ basis set are in good agreement with the previously reported values obtained by using the smaller 4-31G basis set or resulting from DFT calculations (4-31G [5]: $\Delta \mathrm{E}_{\mathrm{II}-\mathrm{I}}=8.91$, $\Delta \mathrm{E}_{\mathrm{III}-\mathrm{I}}=12.33 \mathrm{~kJ} \mathrm{~mol}^{-1}$; DFT [3]: $\Delta \mathrm{E}_{\mathrm{II}-\mathrm{I}}=$ $8.95, \Delta \mathrm{E}_{\mathrm{III}-\mathrm{I}}=12.55 \mathrm{~kJ} \mathrm{~mol}^{-1}$ ). However, the lower level $4-31 \mathrm{G}$ theoretical calculations could only identify 33 of the 38 energy minima of 3AP.

In general, bond lengths and bond angles calculated at the different levels of theory do not show important differences, despite the MP2 calculations lead to slightly longer $\mathrm{OH}, \mathrm{CN}$ and, specially $\mathrm{CO}$ bonds when compared with the Hartree-Fock values, thus matching closer the experimental values obtained by microwave spectroscopy [2]. Moreover, changes in these structural parameters with conformation were also found to be similar at the different levels of theory. Table 1 also compares the 6-31G* calculated values for the main dihedral angles of conformer I with those experimentally obtained [2]. These structural parameters are a good measure of the quality of the theoretical predictions, since they correspond to very flexible co-ordinates, strongly sensitive to intramolecular interactions. The 6-31G* values show a fairly good agreement with the experimental data, pointing to an adequate description by this basis set of the main intramolecular interactions that determine the preferred molecular conformations of 3AP. Since most of the geometric features that characterised the various conformers of $3 \mathrm{AP}$ were already well described elsewhere [5] they do not deserve here further treatment.

Table 2 summarises the $6-31 \mathrm{G}^{*}$ calculated vibrational results obtained for the most populated conformational states (I, II and III) of isolated 3AP. The infrared spectrum of 3AP isolated in an Ar matrix is shown in Fig. 4. The absence of significant contribution of dimers (or higher order aggregates) to the observed spectra was checked by comparison with spectra obtained using low matrix/solute ratios (intensive mark bands of aggregated species appear at 3283, 775 and 767 $\mathrm{cm}^{-1}$ ). The assignment of the observed bands is presented in Table 3 and a simulation of calculated and experimental (Ar matrix) spectra of 3AP, which allows an easier comparison between theoretical and experimental results, is shown in Fig. 5. As it could be anticipated, the vibrational bands owing to the most stable conformer I dominate the spectrum of $3 \mathrm{AP}$ in the low temperature matrix. The fact that the main observed bands occur as doublets (or triplets) could be ascribed to site splitting and demonstrates the existence of non-equivalent matrix sites. Some of the less intensive bands are as a result of conformers II and III. The comparison of the calculated and observed intensities of the bands ascribed to the $v \mathrm{CN}$ and $v \mathrm{OH}$ vibrations of the three conformers (these bands stay in a relatively clean spectral region and could be easily assigned to individual conformers) allows us to evaluate approximately the conformational composition of 3AP in the Ar matrix and to estimate the relative populations of forms I, II and III at the deposition temperature ( $298 \mathrm{~K})$. The results show that, at this temperature, the relative populations of the three experimentally observed conformers are 1:0.021:0.003, which correspond to relative energies of $\Delta \mathrm{E}_{\mathrm{II}-\mathrm{I}}=$ 9.54 and $\Delta \mathrm{E}_{\mathrm{III}-\mathrm{I}}=14.23 \mathrm{~kJ} \mathrm{~mol}^{-1}$, respectively. These values compare fairly well with the corre- 
Table 2

HF 6-31G* calculated relevant vibrational wavenumbers $(v)$ and absolute intensities ( $\mathrm{I}^{\mathrm{ir}}$, infrared; $\mathrm{I}^{\mathrm{R}}$, Raman) for the most populated conformational states of 3-amino-1-propanol ${ }^{\mathrm{a}}$

\begin{tabular}{|c|c|c|c|c|c|c|c|c|c|}
\hline \multirow[t]{2}{*}{ Approximate description ${ }^{\mathrm{b}}$} & \multicolumn{3}{|c|}{ Form I } & \multicolumn{3}{|c|}{ Form II } & \multicolumn{3}{|c|}{ Form III } \\
\hline & $v$ & $\mathrm{I}^{\mathrm{ir}}$ & $I^{R}$ & $v$ & $\mathrm{I}^{\mathrm{ir}}$ & $I^{R}$ & $v$ & $\mathrm{I}^{\mathrm{ir}}$ & $I^{R}$ \\
\hline $\mathrm{vOH}$ & 3590 & 165.2 & 41.3 & 3632 & 70.2 & 38.3 & 3645 & 42.1 & 49.9 \\
\hline$v \mathrm{NH}_{2}$ as. & 3388 & 2.1 & 80.0 & 3386 & 1.0 & 77.8 & 3410 & 7.0 & 54.3 \\
\hline$v \mathrm{NH}_{2} \mathrm{~s}$ & 3313 & 1.4 & 98.4 & 3313 & 0.7 & 98.6 & 3329 & 3.9 & 112.0 \\
\hline$v \mathrm{C} 2 \mathrm{H}_{2}$ as. & 2903 & 78.8 & 109.8 & 2911 & 86.0 & 91.8 & 2909 & 67.1 & 49.1 \\
\hline$v \mathrm{C} 4 \mathrm{H}_{2}$ as. & 2885 & 101.4 & 32.8 & 2903 & 53.4 & 57.3 & 2880 & 67.1 & 111.1 \\
\hline$v \mathrm{C} 3 \mathrm{H}_{2}$ as. & 2868 & 17.7 & 97.2 & 2878 & 41.5 & 57.5 & 2872 & 38.6 & 79.1 \\
\hline$v \mathrm{C} 3 \mathrm{H}_{2} \mathrm{~s}$ & 2844 & 43.6 & 120.8 & 2836 & 66.0 & 80.9 & 2848 & 91.5 & 143.5 \\
\hline$v \mathrm{C} 4 \mathrm{H}_{2} \mathrm{~s}$ & 2812 & 73.4 & 103.1 & 2812 & 70.7 & 84.1 & 2787 & 84.9 & 91.2 \\
\hline $\mathrm{vC} 2 \mathrm{H}_{2} \mathrm{~s}$ & 2811 & 79.9 & 73.8 & 2860 & 48.0 & 146.9 & 2831 & 28.0 & 57.3 \\
\hline$\delta \mathrm{NH} 2$ & 1631 & 40.8 & 7.2 & 1634 & 42.5 & 7.2 & 1633 & 43.4 & 6.9 \\
\hline$\delta \mathrm{C} 2 \mathrm{H}_{2}$ & 1489 & 1.1 & 5.8 & 1484 & 0.3 & 11.5 & 1487 & 0.5 & 5.7 \\
\hline$\delta \mathrm{C} 4 \mathrm{H}_{2}$ & 1478 & 0.5 & 16.1 & 1491 & 1.4 & 8.2 & 1477 & 0.5 & 15.7 \\
\hline$\delta \mathrm{C} 3 \mathrm{H}_{2}$ & 1445 & 20.7 & 8.8 & 1452 & 5.8 & 13.3 & 1444 & 3.6 & 9.3 \\
\hline$\delta \mathrm{COH}$ & 1425 & 95.3 & 7.0 & 1371 & 21.8 & 6.8 & 1341 & 18.6 & 10.7 \\
\hline$\omega \mathrm{C} 4 \mathrm{H}_{2}$ & 1401 & 13.1 & 1.6 & 1411 & 25.4 & 1.8 & 1413 & 39.7 & 3.2 \\
\hline$\omega \mathrm{C} 2 \mathrm{H}_{2}$ & 1368 & 4.8 & 6.8 & 1390 & 47.6 & 4.5 & 1398 & 33.5 & 2.4 \\
\hline$\omega \mathrm{C} 3 \mathrm{H}_{2}$ & 1355 & 0.8 & 1.3 & 1357 & 1.5 & 1.7 & 1360 & 3.5 & 0.3 \\
\hline twC4 $4 \mathrm{H}_{2}$ & 1295 & 3.7 & 11.8 & 1379 & 11.2 & 8.1 & 1312 & 1.8 & 12.0 \\
\hline $\mathrm{twC} 3 \mathrm{H}_{2}$ & 1258 & 7.5 & 10.8 & 1268 & 4.8 & 18.4 & 1177 & 15.1 & 2.5 \\
\hline $\mathrm{twC} 2 \mathrm{H}_{2}$ & 1206 & 17.0 & 4.8 & 1194 & 11.1 & 0.7 & 1255 & 8.1 & 12.2 \\
\hline$\gamma \mathrm{C} 2 \mathrm{H}_{2}$ & 1145 & 5.4 & 3.1 & 978 & 16.3 & 2.6 & 934 & 15.3 & 3.9 \\
\hline $\mathrm{vCO}$ & 1092 & 139.6 & 4.1 & 1088 & 77.9 & 4.6 & 1060 & 63.5 & 10.3 \\
\hline$v \mathrm{CN}$ & 1054 & 28.5 & 7.1 & 1053 & 82.9 & 4.3 & 1048 & 44.3 & 1.9 \\
\hline$\gamma \mathrm{NH}_{2}$ & 1032 & 9.6 & 3.2 & 1138 & 2.9 & 2.4 & 1145 & 10.6 & 3.3 \\
\hline$\omega \mathrm{NH}_{2}$ & 943 & 30.5 & 5.7 & 866 & 121.5 & 4.9 & 902 & 52.4 & 3.2 \\
\hline vCcas. & 920 & 7.8 & 6.4 & 932 & 16.1 & 6.3 & 1084 & 57.9 & 3.2 \\
\hline$\gamma \mathrm{C} 3 \mathrm{H}_{2}$ & 870 & 6.9 & 1.4 & 742 & 7.7 & 0.6 & 870 & 2.5 & 2.5 \\
\hline$\gamma \mathrm{C} 4 \mathrm{H}_{2}$ & 837 & 73.4 & 0.8 & 1009 & 2.7 & 4.7 & 846 & 73.8 & 2.5 \\
\hline vCCs. & 774 & 4.3 & 11.8 & 797 & 11.1 & 12.5 & 771 & 5.9 & 12.0 \\
\hline$\tau \mathrm{HOCC}$ & 605 & 183.6 & 2.8 & 504 & 141.7 & 1.8 & 239 & 158.9 & 2.5 \\
\hline$\delta \mathrm{CCC}$ & 486 & 2.4 & 0.3 & 238 & 2.2 & 0.1 & 490 & 10.8 & 0.4 \\
\hline$\delta \mathrm{OCC}$ & 369 & 12.6 & 1.1 & 563 & 25.0 & 0.4 & 307 & 10.7 & 0.8 \\
\hline$\delta \mathrm{CCN}$ & 312 & 2.0 & 0.5 & 375 & 12.3 & 1.3 & 370 & 58.4 & 1.0 \\
\hline$\tau \mathrm{CCNH}$ & 260 & 32.7 & 0.9 & 296 & 37.5 & 1.9 & 400 & 16.7 & 0.3 \\
\hline$\tau \mathrm{OCCC}$ & 190 & 1.0 & 0.1 & 101 & 3.4 & 0.1 & 117 & 5.2 & 0.1 \\
\hline$\tau \mathrm{CCCN}$ & 120 & 5.4 & 0.2 & 182 & 2.4 & 0.1 & 145 & 40.1 & 1.1 \\
\hline
\end{tabular}

${ }^{a}$ Wavenumbers in $\mathrm{cm}^{-1}$; wavenumbers were scaled by 0.89 . Intensities in $\mathrm{km} \mathrm{mol}^{-1}$.

${ }^{\mathrm{b}}$ Abbreviations: $v$, stretching; $\delta$, bending; $\gamma$, rocking; $\omega$, wagging; $\tau$, torsion; tw, twisting.

sponding MP2/6-31G* calculated values (8.82 and $12.77 \mathrm{~kJ} \mathrm{~mol}^{-1}$ ).

The values of the $\mathrm{OH}$ stretching frequencies (main component band) for the conformational ground states in the Ar matrix for $2 \mathrm{AE}$ and $3 \mathrm{AP}$, are $3555 \mathrm{~cm}^{-1}[1,18]$ and $3417 \mathrm{~cm}^{-1}$, respectively, being consistent with the expected existence of a stronger intramolecular $\mathrm{OH}-\mathrm{N}$ hydrogen bond in 3AP. It is also worth to mention that the vibrational calculations show the occurrence of an extensive coupling of co-ordinates in 3AP (see Table 3). This result can be correlated with the great torsional flexibility of this molecule and further reinforces the importance of intramolecular interactions in this system. 
Fig. 6 shows the $\mathrm{vOH}$ region of the infrared spectra of $3 \mathrm{AP}$ in $\mathrm{CCl}_{4}$ solution, at different concentrations. In these spectra, besides the typical broad band as a result of aggregates, bands as a result of monomeric species can be observed. The two low intensity bands appearing at the higher frequencies (3684 and $3639 \mathrm{~cm}^{-1}$ ), can be assigned to monomeric forms III and II, respectively, while the band at $3396 \mathrm{~cm}^{-1}$, which is superimposed with the band resulting from the aggregates, is ascribable to the conformational ground state (form I). These bands are observed at frequencies close to those of the corresponding bands in the spectra of the Ar-matrix isolated 3AP (3706, 3660 and $3417 \mathrm{~cm}^{-1}$; see Table 4) though they are slightly red-shifted because of the higher effective polarity of the solvent.

The liquid phase infrared and Raman spectra of 3AP are shown in Fig. 7. The assignments of the observed bands in both spectra are presented in Table 4. Most of the bands of the spectra of the aggregates can be fairly well assigned taken as reference the calculated spectra of monomeric form III, indicating that this is the preferred conformation assumed by the monomeric units within the aggregates. As previously mentioned, the intramolecular $\mathrm{NH}-\mathrm{O}$ hydrogen bond exhibited by this conformer (that is the lowest energy form having an intramolecular $\mathrm{NH}-\mathrm{O}$ hydrogen bonding in isolated 3AP) makes the hydroxyl group more acidic and the amino group more basic and then activates both $\mathrm{OH}$ and $\mathrm{NH}_{2}$ groups to the establishment of the intermolecular $\mathrm{OH}-\mathrm{N}$ hydrogen bonding which is the dominant intermolecular interaction present in the aggregated species. The importance of this intermolecular hydrogen bonding in liquid 3AP is also reflected in the frequencies of the bands assigned to $\mathrm{vOH}$, which strongly decrease when compared with those of the free monomeric species, and to $\delta \mathrm{COH}$ and $\tau \mathrm{HOCC}$, that increase when the $\mathrm{OH}$ group is involved in the intermolecular $\mathrm{H}$-bonding [20]. These results are in agreement with the conclusions of our previous study in $2 \mathrm{AE}$, where a conformation structurally similar to form III of 3AP was also found to be the preferred configuration assumed by the monomeric units within the aggregates, in the liquid phase [1].

On the other hand, very interestingly, in contrast with the results obtained for $2 \mathrm{AE}$, there are spectroscopic evidences that some molecules adopting the conformational ground state of isolated 3AP-form I-are also present in the pure liquid. In particular, the infrared bands at 1224, 1149, 940 (this later also observed in the Raman spectrum) and $776 \mathrm{~cm}^{-1}$ assigned to the twC2 $\mathrm{H}_{2}$, $\gamma \mathrm{C}_{2} \mathrm{H}_{2}, \omega \mathrm{NH}_{2}$ and vCCs. vibrations, respectively, are ascribable to monomeric form I (see Table 3 for comparison with the frequencies of the corresponding bands in the matrix isolation spectrum

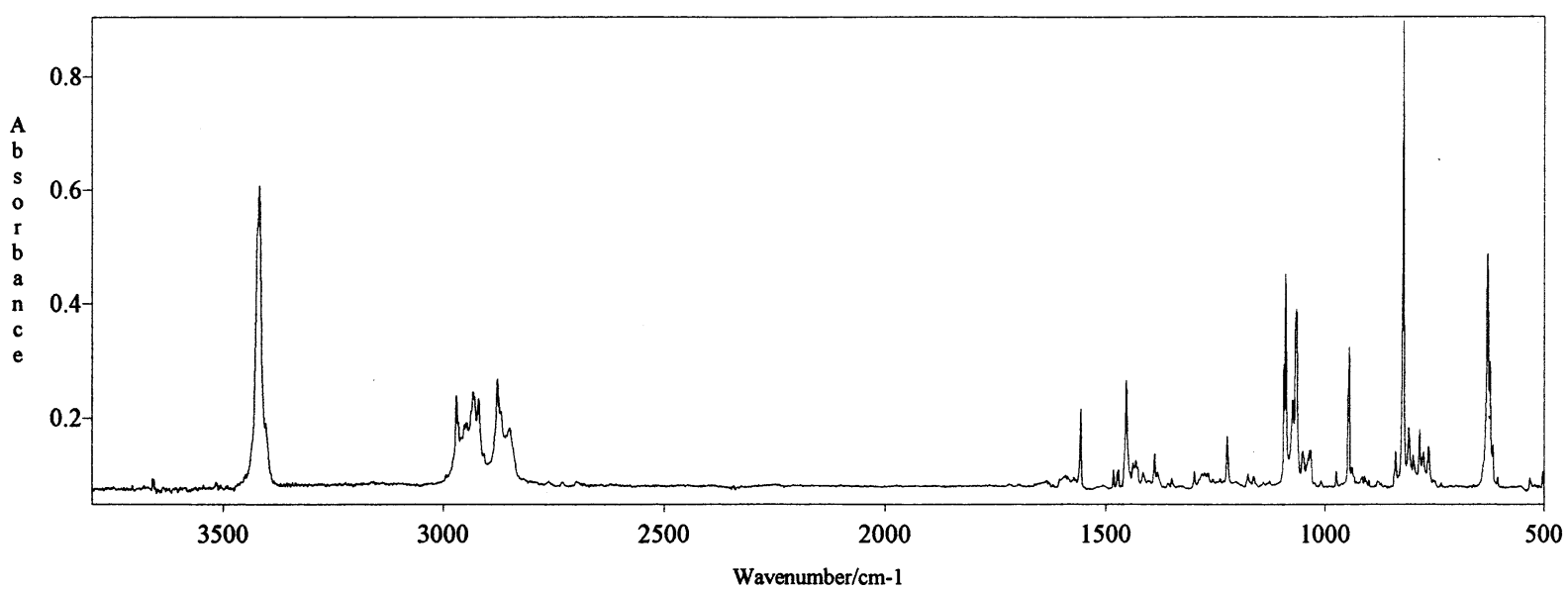

Fig. 4. Low temperature (14 K) infrared spectrum of 3-amino-1-propanol isolated in an Ar matrix (baseline corrected; water bands subtracted). 
Table 3

Gas phase [19] and low temperature matrix isolation spectroscopy infrared vibrational spectra, HF 6-31G* calculated relevant infrared wavenumbers and intensities for the most populated conformational states of 3-aminopropanol and calculated potential energy distributions (PEDs) for the vibrations of the conformational ground state (I) ${ }^{\mathrm{a}}$

\begin{tabular}{|c|c|c|c|c|c|c|c|}
\hline \multicolumn{2}{|c|}{ Gas phase } & \multicolumn{2}{|l|}{$\mathrm{MIS}^{\mathrm{b}}$} & \multicolumn{2}{|c|}{ Calculated } & \multirow[t]{2}{*}{$\mathrm{PED}^{\mathrm{c}}$} & \multirow[t]{2}{*}{ Assignment ${ }^{\mathrm{e}}$} \\
\hline$v$ & I & $v$ & I & $v$ & I & & \\
\hline 3675 & $\mathrm{~m}$ & 3706 & 0.1 & 3645 & 0.9 & & $v O H \mathrm{III}$ \\
\hline 3549 & sh & 3660 & 2.0 & 3632 & 5.0 & & $v O H \mathrm{II}$ \\
\hline \multirow[t]{4}{*}{3494} & $\mathrm{~m}$ & 3417 & 151.0 & 3590 & 165.2 & vOH(99.9) & $v \mathrm{OH}$ \\
\hline & & $3402^{\mathrm{d}}$ & 16.2 & & & & \\
\hline & & & & 3388 & 2.1 & $v \mathrm{NH}_{2}$ as. $(98.7)$ & $v \mathrm{NH}_{2}$ as. \\
\hline & & & & 3313 & 1.4 & $v \mathrm{NH}_{2}$ s. $(98.6)$ & $v \mathrm{NH}_{2} \mathrm{~s}$ \\
\hline \multirow[t]{5}{*}{2939} & vs & 2971 & 41.6 & 2903 & 78.8 & $v \mathrm{C} 2 \mathrm{H}_{2}$ as. $(63.9)+v \mathrm{C} 2 \mathrm{H}_{2}$ s. $(33.1)$ & $v \mathrm{C} 2 \mathrm{H}_{2}$ as. \\
\hline & & 2967 & 3.1 & 2911 & 6.1 & & $v \mathrm{C} 2 \mathrm{H}_{2}$ as.II \\
\hline & & 2953 & 1.5 & 2909 & 1.6 & & $v \mathrm{C} 2 \mathrm{H}_{2}$ as.III \\
\hline & & 2947 & 3.3 & 2903 & 3.8 & & $v C 4 H 2 a s$. II \\
\hline & & 2937 & 2.2 & 2880 & 1.4 & & vC4H2as.III \\
\hline \multirow[t]{2}{*}{2922} & sh & 2932 & 29.4 & 2885 & 101.4 & $v \mathrm{C} 3 \mathrm{H}_{2}$ as. $(40.7)+v \mathrm{C} 4 \mathrm{H}_{2}$ as. $(38.9)+v \mathrm{C} 4 \mathrm{H}_{2} \mathrm{~s} .(18.2)$ & $v \mathrm{C} 4 \mathrm{H}_{2}$ as. \\
\hline & & 2929 & 6.2 & 2878 & 2.9 & & $v \mathrm{C}_{3} \mathrm{H}_{2}$ as.II \\
\hline \multirow[t]{2}{*}{2922} & sh & 2920 & 35.9 & 2868 & 17.7 & $v \mathrm{C} 3 \mathrm{H}_{2}$ as.(57.7) $+v \mathrm{C} 4 \mathrm{H}_{2}$ as.(30.6) & $v \mathrm{C} 3 \mathrm{H}_{2}$ as. \\
\hline & & 2907 & 3.4 & 2860 & 3.4 & & $v \mathrm{C} 2 \mathrm{H}_{2} \mathrm{~s}$.II \\
\hline \multirow[t]{2}{*}{2822} & $\mathrm{~s}$ & 2877 & 37.7 & 2844 & 43.6 & $v \mathrm{C} 3 \mathrm{H}_{2} \mathrm{~s} .(90.6)$ & $v \mathrm{C} 3 \mathrm{H}_{2} \mathrm{~s}$ \\
\hline & & 2873 & 5.5 & 2836 & 4.7 & & $v \mathrm{C} 3 \mathrm{H}_{2} \mathrm{~S} . \mathrm{II}$ \\
\hline \multirow[t]{2}{*}{2822} & s & 2869 & 29.5 & 2812 & 73.4 & $v \mathrm{C} 4 \mathrm{H}_{2}$ s. $(57.2)+v \mathrm{C} 4 \mathrm{H}_{2}$ as. (27.8) & $v \mathrm{C} 4 \mathrm{H}_{2} \mathrm{~s}$ \\
\hline & & 2856 & 4.6 & 2812 & 5.0 & & $v \mathrm{C}_{4} \mathrm{H}_{2} \mathrm{~s} . \mathrm{II}$ \\
\hline 2780 & $\mathrm{sh}$ & 2848 & 45.8 & 2811 & 79.9 & $v \mathrm{C} 2 \mathrm{H}_{2} \mathrm{~s} .(57.5)+v \mathrm{C} 2 \mathrm{H}_{2}$ as. (31.9) & $v \mathrm{C} 2 \mathrm{H}_{2} \mathrm{~s}$ \\
\hline 1624 & $\mathrm{~m}$ & 1557 & 30.6 & 1631 & 40.8 & $\delta \mathrm{NH}_{2}(79.1)+\omega \mathrm{NH}_{2}(19.4)$ & $\delta \mathrm{NH}_{2}$ \\
\hline 1487 & $\mathrm{sh}$ & 1482 & 16.6 & 1489 & 1.1 & $\delta \mathrm{C} 2 \mathrm{H}_{2}(66.7)+\delta \mathrm{C} 4 \mathrm{H}_{2}(29.0)$ & $\delta \mathrm{C} 2 \mathrm{H}_{2}$ \\
\hline \multirow[t]{2}{*}{1468} & sh & 1473 & 9.5 & 1478 & 0.5 & $\delta \mathrm{C} 4 \mathrm{H}_{2}(65.7)+\delta \mathrm{C} 2 \mathrm{H}_{2}(28.9)$ & $\delta \mathrm{C} 4 \mathrm{H}_{2}$ \\
\hline & & $1471^{\mathrm{d}}$ & 3.5 & & & & \\
\hline \multirow[t]{2}{*}{1435} & $\mathrm{~m}$ & 1453 & 72.4 & 1425 & 95.3 & $\omega \mathrm{C} 2 \mathrm{H}_{2}(38.7)+\delta \mathrm{COH}(32.7)$ & $\delta \mathrm{COH}$ \\
\hline & & 1438 & 5.4 & 1452 & 0.4 & & $\delta C 3 \mathrm{H}_{2}$ II \\
\hline \multirow[t]{6}{*}{1435} & $\mathrm{~m}$ & 1431 & 9.7 & 1445 & 20.7 & $\delta \mathrm{C} 3 \mathrm{H}_{2}(84.1)$ & $\delta \mathrm{C} 3 \mathrm{H}_{2}$ \\
\hline & & $1427^{\mathrm{d}}$ & 7.8 & & & & \\
\hline & & 1419 & 1.6 & 1413 & 0.8 & & $\omega C 4 \mathrm{H}_{2} \mathrm{III}$ \\
\hline & & 1415 & 0.9 & 1411 & 1.8 & & $\omega C 4 \mathrm{H}_{2} \mathrm{II}$ \\
\hline & & 1403 & 0.5 & 1398 & 0.7 & & $\omega \mathrm{C} 2 \mathrm{H}_{2} \mathrm{III}$ \\
\hline & & 1399 & 0.6 & 1390 & 3.4 & & $\omega \mathrm{C} 2 \mathrm{H}_{2} \mathrm{II}$ \\
\hline \multirow[t]{2}{*}{1390} & $\mathrm{~m}$ & 1388 & 14.7 & 1401 & 13.1 & $\omega \mathrm{C} 4 \mathrm{H}_{2}(62.6)$ & $\omega \mathrm{C} 4 \mathrm{H}_{2}$ \\
\hline & & 1382 & 0.5 & 1371 & 1.5 & & $\delta C O H \mathrm{II}$ \\
\hline \multirow[t]{5}{*}{1370} & $\mathrm{sh}$ & 1374 & 4.2 & 1368 & 4.8 & $\omega \mathrm{C} 2 \mathrm{H}_{2}(23.0)+t w C 2 \mathrm{H}_{2}(18.5)+\delta \mathrm{COH}(18.1)+\omega \mathrm{C} 3 \mathrm{H}_{2}(15.8)$ & $\omega \mathrm{C} 2 \mathrm{H}_{2}$ \\
\hline & & 1359 & 0.2 & 1357 & 0.1 & & $\omega C 3 H \mathrm{II}$ \\
\hline & & 1350 & 1.4 & 1355 & 0.8 & $\omega \mathrm{C} 3 \mathrm{H}_{2}(44.8)+\omega \mathrm{C} 2 \mathrm{H}_{2}(23.3)+\omega \mathrm{C} 4 \mathrm{H}_{2}(10.9)$ & $\omega \mathrm{C} 3 \mathrm{H}_{2}$ \\
\hline & & $1348^{\mathrm{d}}$ & 2.8 & & & & \\
\hline & & 1345 & 0.1 & 1341 & 0.4 & & $\delta C O H \mathrm{III}$ \\
\hline \multirow[t]{3}{*}{1296} & vw & 1298 & 4.1 & 1295 & 3.7 & twC4 $\mathrm{H}_{2}(33.8)+\gamma \mathrm{NH}_{2}(25.4)$ & twC4 $\mathrm{H}_{2}$ \\
\hline & & 1288 & 0.2 & 1279 & 0.8 & & $t w C 4 H_{2} \mathrm{II}$ \\
\hline & & 1269 & 1.0 & 1268 & 0.3 & & $t w C 3 \mathrm{H}_{2} \mathrm{II}$ \\
\hline \multirow[t]{2}{*}{1277} & $\mathrm{w}$ & 1266 & 3.6 & 1258 & 7.5 & $\mathrm{twC} 3 \mathrm{H}_{2}(31.3)+\mathrm{twC} 4 \mathrm{H}_{2}(28.0)+\mathrm{twC}_{2} \mathrm{H}_{2}(13.3)$ & $\mathrm{twC} 3 \mathrm{H}_{2}$ \\
\hline & & 1239 & 0.2 & 1255 & 0.2 & & $t w C 2 \mathrm{H}_{2} \mathrm{III}$ \\
\hline \multirow[t]{2}{*}{1237} & $\mathrm{w}$ & 1223 & 24.8 & 1206 & 17.0 & $\mathrm{twC} 2 \mathrm{H}_{2}(34.3)+\delta \mathrm{COH}(18.4)+\mathrm{twC} 3 \mathrm{H}_{2}(11.0)$ & $\mathrm{twC} 2 \mathrm{H}_{2}$ \\
\hline & & 1211 & 0.6 & 1194 & 0.8 & & $t w C 2 \mathrm{H}_{2} \mathrm{II}$ \\
\hline 1141 & sh & 1177 & 5.2 & 1145 & 5.4 & $\operatorname{twC} 3 \mathrm{H}_{2}(14.2)+\gamma \mathrm{C} 2 \mathrm{H}_{2}(12.1)+v \mathrm{CO}(11.8)+\mathrm{twC}_{2} \mathrm{H}_{2}(11.6)$ & $\gamma \mathrm{C} 2 \mathrm{H}_{2}$ \\
\hline & & & & & & $+\gamma \mathrm{NH}_{2}(10.0)$ & \\
\hline & & 1165 & 0.1 & 1177 & 0.3 & & $t w C 3 \mathrm{H}_{2} \mathrm{III}$ \\
\hline & & 1159 & 0.1 & 1145 & 0.2 & & $\gamma \mathrm{NH}_{2} \mathrm{III}$ \\
\hline & & 1127 & 2.3 & 1138 & 0.2 & & $\gamma \mathrm{NH}_{2} \mathrm{II}$ \\
\hline
\end{tabular}


Table 3 (continued)

\begin{tabular}{|c|c|c|c|c|c|c|c|}
\hline \multicolumn{2}{|c|}{ Gas phase } & \multicolumn{2}{|l|}{$\mathrm{MIS}^{\mathrm{b}}$} & \multicolumn{2}{|c|}{ Calculated } & \multirow[t]{2}{*}{$\mathrm{PED}^{\mathrm{c}}$} & \multirow[t]{2}{*}{ Assignment ${ }^{\mathrm{e}}$} \\
\hline$v$ & I & $v$ & I & $v$ & I & & \\
\hline \multirow[t]{5}{*}{1073} & $\mathrm{~s}$ & 1095 & 44.3 & 1092 & 139.6 & $\nu \mathrm{CO}(46.8)$ & $v \mathrm{CO}$ \\
\hline & & $1092^{\mathrm{d}}$ & 45.6 & & & & \\
\hline & & 1088 & 0.7 & 1084 & 1.2 & & vCCas.III \\
\hline & & 1078 & 3.5 & 1088 & 5.5 & & $v C O \mathrm{II}$ \\
\hline & & $1075^{\mathrm{d}}$ & 5.6 & & & & \\
\hline \multirow[t]{5}{*}{1066} & s & 1069 & 43.7 & 1054 & 28.5 & $v \mathrm{CN}(55.0)+v \mathrm{CCas} .(25.3)$ & $v \mathrm{CN}$ \\
\hline & & $1067^{\mathrm{d}}$ & 62.7 & & & & \\
\hline & & $1065^{\mathrm{d}}$ & 67.7 & & & & \\
\hline & & 1052 & 1.7 & 1053 & 5.9 & & $v C N \mathrm{II}$ \\
\hline & & 1049 & 0.7 & 1048 & 1.0 & & $v C N$ III \\
\hline \multirow[t]{4}{*}{1054} & sh & 1037 & 15.7 & 1032 & 9.6 & $\gamma \mathrm{NH}_{2}(26.4)+v \mathrm{CO}(15.4)+\gamma \mathrm{C}_{4} \mathrm{H}_{2}(11.6)+\mathrm{twC} \mathrm{H}_{2}(10.1)$ & $\gamma \mathrm{NH}_{2}$ \\
\hline & & $1034^{\mathrm{d}}$ & 23.1 & & & & \\
\hline & & 1009 & 1.6 & 1009 & 0.2 & & $\gamma \mathrm{C}_{4} \mathrm{H}_{2} \mathrm{II}$ \\
\hline & & 974 & 1.2 & 978 & 1.1 & & $\gamma \mathrm{C} 2 \mathrm{H}_{2} \mathrm{II}$ \\
\hline \multirow[t]{4}{*}{942} & vw & 947 & 24.7 & 943 & 30.5 & $\omega \mathrm{NH}_{2}(38.4)+\mathrm{twC} 4 \mathrm{H}_{2}(13.2)+\gamma \mathrm{C}_{3} \mathrm{H}_{2}(11.3)$ & $\omega \mathrm{NH}_{2}$ \\
\hline & & $945^{\mathrm{d}}$ & 34.6 & & & & \\
\hline & & 939 & 0.8 & 932 & 1.1 & & $v$ CCas.II \\
\hline & & 933 & 0.7 & 934 & 0.3 & & $\gamma \mathrm{C}_{2} \mathrm{H}_{2} \mathrm{III}$ \\
\hline \multirow[t]{4}{*}{907} & $\mathrm{w}$ & 915 & 7.9 & 920 & 7.8 & $v$ Ccas. $(29.3)+v \mathrm{CN}(27.6)$ & vCCas. \\
\hline & & $910^{\mathrm{d}}$ & 6.1 & & & & \\
\hline & & 900 & 0.2 & 902 & 1.1 & & $\omega \mathrm{NH}_{2} \mathrm{III}$ \\
\hline & & 882 & 0.7 & 870 & 0.1 & & $\gamma \mathrm{C} 3 \mathrm{H} 2 \mathrm{III}$ \\
\hline \multirow[t]{3}{*}{876} & $\mathrm{w}$ & 872 & 1.8 & 870 & 6.9 & $\gamma \mathrm{C} 2 \mathrm{H}_{2}(29.9)+\gamma \mathrm{C} 3 \mathrm{H}_{2}(15.6)+\gamma \mathrm{C} 4 \mathrm{H}_{2}(10.5)$ & $\gamma \mathrm{C}_{3} \mathrm{H}_{2}$ \\
\hline & & 856 & 0.1 & 846 & 1.6 & & $\gamma \mathrm{C}_{4} \mathrm{H}_{2} \mathrm{III}$ \\
\hline & & 839 & 2.7 & 866 & 8.6 & & $\omega \mathrm{NH}_{2} \mathrm{II}$ \\
\hline \multirow[t]{5}{*}{810} & sh & 821 & 56.8 & 837 & 73.4 & $\omega \mathrm{NH}_{2}(39.2)+\gamma \mathrm{C} 4 \mathrm{H}_{2}(31.0)$ & $\gamma \mathrm{C}_{4} \mathrm{H}_{2}$ \\
\hline & & $823^{\mathrm{d}}$ & 32.9 & & & & \\
\hline & & 809 & 5.0 & 797 & 0.8 & & $v C C s . \mathrm{II}$ \\
\hline & & $807^{\mathrm{d}}$ & 1.6 & & & & \\
\hline & & $799^{\mathrm{d}}$ & 2.7 & & & & \\
\hline \multirow[t]{5}{*}{780} & $\mathrm{~m}$ & 784 & 16.4 & 774 & 4.3 & vCCs.(68.8) & vCCs. \\
\hline & & $775^{\mathrm{d}}$ & 3.3 & & & & \\
\hline & & 765 & 2.3 & 771 & 0.1 & & $v C C s . \mathrm{III}$ \\
\hline & & $763^{\mathrm{d}}$ & 0.2 & & & & \\
\hline & & 736 & 0.3 & 742 & 0.5 & & $\gamma \mathrm{C} 3 \mathrm{H}_{2} \mathrm{II}$ \\
\hline \multirow[t]{11}{*}{674} & $\mathrm{w}$ & 631 & 106.5 & 605 & 183.6 & $\tau \mathrm{HOCC}(88.9)$ & $\tau \mathrm{HOCC}$ \\
\hline & & $634^{\mathrm{d}}$ & 54.9 & & & & \\
\hline & & $625^{\mathrm{d}}$ & 8.0 & & & & \\
\hline & & 532 & 5.5 & 563 & 1.8 & & $\delta O C C \mathrm{II}$ \\
\hline & & 502 & 3.9 & 504 & 10.0 & & $\tau H O C C \mathrm{II}$ \\
\hline & & & & 486 & 2.4 & $\delta \mathrm{CCC}(22.7)+\delta \mathrm{CCN}(20.1)+\gamma \mathrm{C}_{3} \mathrm{H}_{2}(20.0)+\delta \mathrm{OCC}(18.5)$ & $\delta \mathrm{CCC}$ \\
\hline & & & & 369 & 12.6 & $\delta \mathrm{OCC}(44.1)+\delta \mathrm{CCN}(21.0)$ & $\delta \mathrm{OCC}$ \\
\hline & & & & 312 & 2.0 & $\delta \mathrm{CCN}(26.4)+\delta \mathrm{CCC}(23.4)+\tau \mathrm{OCCC}(19.2)+\tau \operatorname{CCCN}(11.0)$ & $\delta \mathrm{CCN}$ \\
\hline & & & & 260 & 32.7 & $\tau \mathrm{CCNH}(56.4)+\tau \mathrm{HOCC}(19.1)+\delta \mathrm{CCC}(15.2)$ & $\tau \mathrm{CCNH}$ \\
\hline & & & & 190 & 1.0 & $\tau \mathrm{OCCC}(50.4)+\tau \mathrm{CCCN}(37.4)$ & $\tau \mathrm{OCCC}$ \\
\hline & & & & 120 & 5.4 & $\tau \mathrm{CCCN}(32.7)+\tau \mathrm{HOCC}(31.5)+\tau \mathrm{OCCC}(28.4)$ & $\tau \mathrm{CCCN}$ \\
\hline
\end{tabular}

\footnotetext{
${ }^{a}$ Wavenumbers in $\mathrm{cm}^{-1}$; calculated wavenumbers were scaled by 0.89 . MIS experimental intensities are normalised integrated intensities $\left(\mathrm{I}_{\mathrm{i}}^{\text {obs }}\right.$ ) obtained using the formula $\mathrm{I}_{\mathrm{i}}=\mathrm{I}_{\mathrm{i}}^{\text {obs }} \times \Sigma \mathrm{I}_{\mathrm{i}}^{\text {cal }} / \Sigma \mathrm{I}_{\mathrm{i}}^{\text {obs }}$ (where $\Sigma \mathrm{I}_{\mathrm{i}}^{\text {cal }}$, sum of the calculated intensities; $\Sigma \mathrm{I}_{\mathrm{i}}^{\text {obs }}$, sum of the observed intensities; i, observed band); integrated intensities were measured after deconvolution. Calculated intensities $\left(\mathrm{Km} \mathrm{mol}^{-1}\right)$ are presented as relative intensities to form I taking into consideration the populations of the conformational states. Data related to forms II and III are given in italic.

${ }^{\mathrm{b}}$ Infrared in Ar matrix.

${ }^{\mathrm{c}}$ Only PED values larger than $10 \%$ are shown in this table.

d Site splitting.

e Abbreviations: $v$, stretching; $\delta$, bending; $\gamma$, rocking; $\omega$, wagging; $\tau$, torsion; tw, twisting.
} 


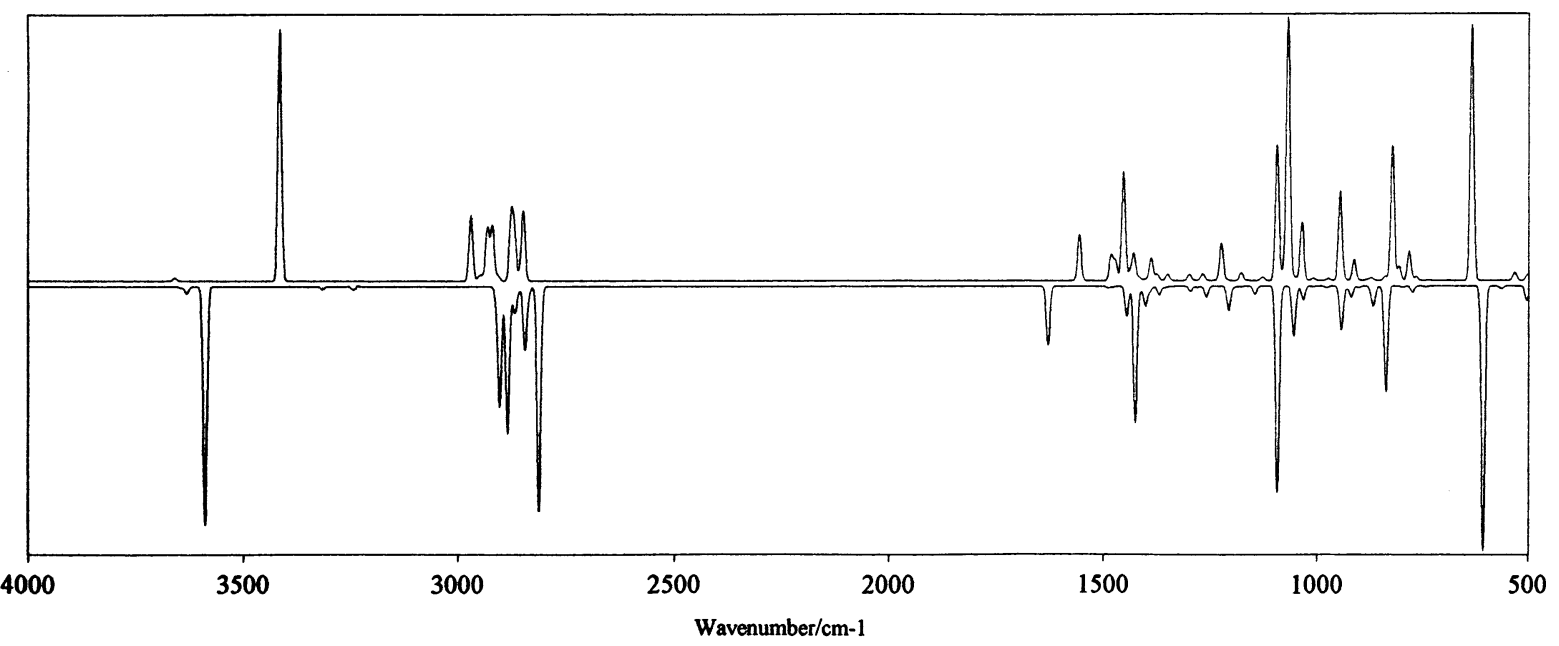

Fig. 5. Simulation of the Ar matrix (lower) and calculated HF 6-31G* (upper) spectra of 3-amino-1-propanol in the $4000-500 \mathrm{~cm}^{-1}$ spectral region, obtained by gaussian synthesis from the experimental and ab initio frequencies and intensities (constant half band width assumed). Calculated wavenumbers were scaled by 0.89 . Calculated intensities presented as relative intensities to form $\mathbf{I}$ (considering the predicted populations of the conformational states); experimental intensities are normalised intensities [ $\mathrm{I}_{\mathrm{i}}^{\mathrm{obs}}$ (norm)] obtained from the area of each observed peak, subjected to previous deconvolution $\left(I_{i}^{\text {obs }}\right)$, by using the formula $I_{i}^{\text {obs }}($ norm $)=I_{i}^{\text {obs }} \times$ $\Sigma \mathrm{I}_{\mathrm{i}}^{\text {cal }} / \Sigma \mathrm{I}_{\mathrm{i}}^{\text {obs }}$ (where $\Sigma \mathrm{I}_{\mathrm{i}}^{\text {cal }}$, sum of the calculated intensities; $\Sigma \mathrm{I}_{\mathrm{i}}^{\text {obs }}$, sum of the observed intensities; i, observed band). When site splitting occurs, experimental wavenumbers correspond to weighted averages $\left[v^{\text {obs }}=\Sigma v^{\text {iobs }} \times I^{\text {iobs }}(\right.$ norm $) / \Sigma I_{i}^{\text {obs }}($ norm $\left.)\right]$ and intensities are the sum of the intensities of all component bands. The total intensity of each spectrum was normalised to unit.

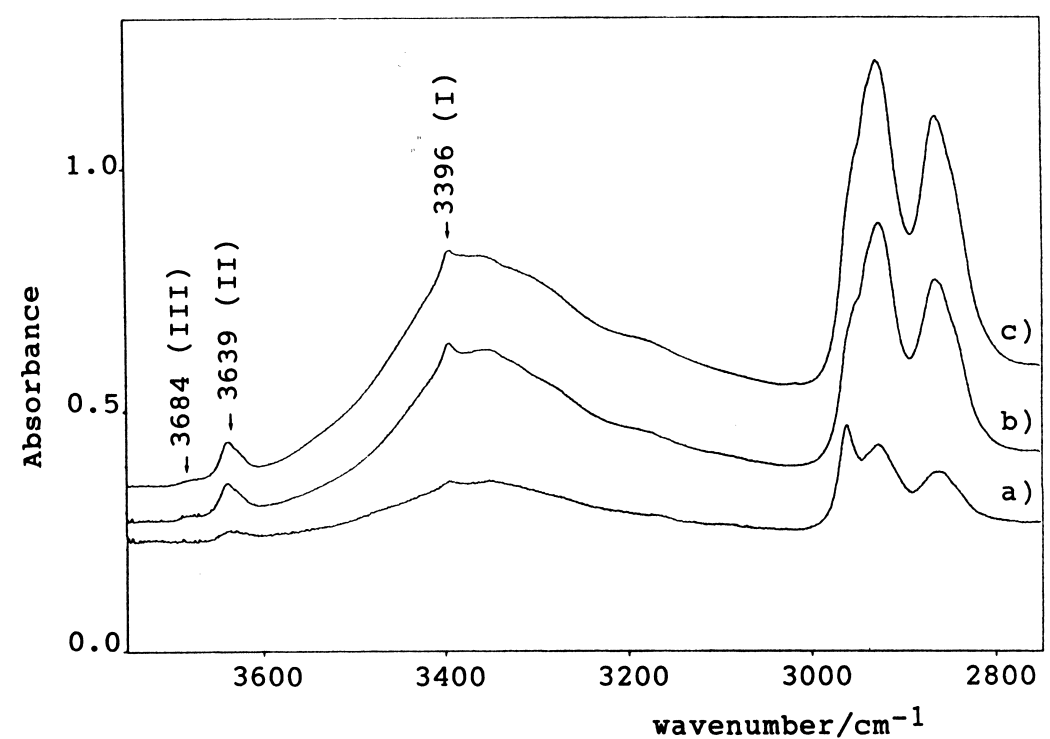

Fig. 6. Infrared spectra (3750-2750 $\mathrm{cm}^{-1}$ region) of 3-amino-1-propanol in $\mathrm{CCl}_{4}$ solution, at room temperature. Concentrations are: (a) $15 \mathrm{mM}$; (b) $100 \mathrm{mM}$; and (c) $500 \mathrm{mM}$. 
Table 4

Comparison of the infrared and Raman spectra of pure liquid with the calculated spectra of form III (see text) ${ }^{\mathrm{a}}$

\begin{tabular}{|c|c|c|c|c|c|c|c|c|}
\hline \multicolumn{2}{|c|}{ Infrared } & \multicolumn{2}{|c|}{ Raman } & \multicolumn{3}{|c|}{ Calculated } & \multirow[t]{2}{*}{$\mathrm{PED}^{\mathrm{b}}$} & \multirow[t]{2}{*}{ Assignment ${ }^{\mathrm{d}}$} \\
\hline$v$ & $\mathrm{I}^{\mathrm{ir}}$ & $v$ & $\mathrm{I}^{\mathrm{R}}$ & $v$ & $\mathrm{I}^{\mathrm{ir}}$ & $I^{R}$ & & \\
\hline 3353 & vs & 3368 & 25.0 & 3410 & 7.0 & 54.3 & $v \mathrm{NH}_{2}$ as.(97.4) & $v \mathrm{NH}_{2}$ as. \\
\hline 3290 & vs & 3310 & 80.4 & 3329 & 3.9 & 112.0 & $v \mathrm{NH}_{2} \mathrm{~s} .(97.7)$ & $v \mathrm{NH}_{2} \mathrm{~s}$ \\
\hline \multirow[t]{2}{*}{3193} & vs & 3196 & 40.0 & $3645^{\mathrm{c}}$ & 42.1 & 49.9 & vOH $(100)$ & $v \mathrm{OH}$ \\
\hline & & 2958 & 37.5 & 2909 & 75.5 & 49.1 & $v \mathrm{C} 2 \mathrm{H}_{2}$ as. $(68.6)+v \mathrm{C} 2 \mathrm{H}_{2} \mathrm{~s} .(24.6)$ & $v \mathrm{C} 2 \mathrm{H}_{2}$ as. \\
\hline \multirow[t]{3}{*}{2935} & vs & 2918 & 130.0 & 2880 & 67.1 & 111.1 & $v \mathrm{C} 4 \mathrm{H}_{2}$ as. $(58.2)+v \mathrm{C} 4 \mathrm{H}_{2}$ s. $(36.4)$ & $v \mathrm{C} 4 \mathrm{H}_{2}$ as. \\
\hline & & 2911 & 87.0 & 2872 & 38.6 & 79.1 & $v \mathrm{C} 3 \mathrm{H}_{2}$ as.(91.9) & $v \mathrm{C} 3 \mathrm{H}_{2}$ as. \\
\hline & & 2878 & 84.4 & 2848 & 91.5 & 143.5 & $v \mathrm{C} 3 \mathrm{H}_{2}$ s. $(49.4)+v \mathrm{C} 2 \mathrm{H}_{2}$ s. $(36.3)+v \mathrm{C} 2 \mathrm{H}_{2}$ as. (10.4) & $v \mathrm{C} 3 \mathrm{H}_{2} \mathrm{~s}$ \\
\hline \multirow[t]{2}{*}{2872} & vs & 2858 & 28.2 & 2831 & 28.0 & 57.3 & $v \mathrm{C} 3 \mathrm{H}_{2}$ s. $(44.6)+v \mathrm{C} 2 \mathrm{H}_{2}$ s. $(37.4)+v \mathrm{C} 2 \mathrm{H}_{2}$ as. (15.8) & $v \mathrm{C} 2 \mathrm{H}_{2} \mathrm{~s}$ \\
\hline & & 2840 & 5.1 & 2787 & 84.9 & 91.2 & $v \mathrm{C} 4 \mathrm{H}_{2}$ s. $(60.7)+v \mathrm{C} 4 \mathrm{H}_{2}$ as. $(37.7)$ & $v \mathrm{C} 4 \mathrm{H}_{2} \mathrm{~s}$ \\
\hline 1599 & $\mathrm{~s}$ & 1615 & 9.2 & 1633 & 43.4 & 6.9 & $\delta \mathrm{NH}_{2}(78.4)+\omega \mathrm{NH}_{2}(20.1)$ & $\delta \mathrm{NH}_{2}$ \\
\hline \multirow[t]{2}{*}{1475} & $\mathrm{~m}$ & 1486 & 16.2 & 1487 & 0.5 & 5.7 & $\delta \mathrm{C} 2 \mathrm{H}_{2}(67.0)+\delta \mathrm{C} 4 \mathrm{H}_{2}(29.3)$ & $\delta \mathrm{C} 2 \mathrm{H}_{2}$ \\
\hline & & 1480 & 17.4 & 1477 & 0.5 & 15.7 & $\delta \mathrm{C} 4 \mathrm{H}_{2}(66.0)+\delta \mathrm{C} 2 \mathrm{H}_{2}(28.6)$ & $\delta \mathrm{C}_{4} \mathrm{H}_{2}$ \\
\hline \multirow[t]{2}{*}{1430} & $\mathrm{~m}$ & 1450 & 16.3 & 1444 & 3.6 & 9.3 & $\delta \mathrm{C} 3 \mathrm{H}_{2}(92.6)$ & $\delta \mathrm{C} 3 \mathrm{H}_{2}$ \\
\hline & & 1410 & 0.8 & 1413 & 39.7 & 3.2 & $\omega \mathrm{C} 4 \mathrm{H}_{2}(51.5)+\omega \mathrm{C} 2 \mathrm{H}_{2}(17.5)$ & $\omega \mathrm{C} 4 \mathrm{H}_{2}$ \\
\hline 1393 & $\mathrm{sh}$ & & & 1398 & 33.5 & 2.4 & $\omega \mathrm{C} 2 \mathrm{H}_{2}(47.0)+v \mathrm{Ccas} .(12.9)$ & $\omega \mathrm{C} 2 \mathrm{H}_{2}$ \\
\hline 1374 & $\mathrm{~m}$ & 1378 & 16.8 & 1360 & 3.5 & 0.3 & $\omega \mathrm{C} 3 \mathrm{H}_{2}(48.3)+\omega \mathrm{C} 2 \mathrm{H}_{2}(16.1)+\omega \mathrm{C} 4 \mathrm{H}_{2}(10.1)$ & $\omega \mathrm{C} 3 \mathrm{H}_{2}$ \\
\hline 1353 & $\mathrm{~m}$ & & & $1341^{\mathrm{c}}$ & 18.6 & 10.7 & $\delta \mathrm{COH}(34.5)+\mathrm{twC} 2 \mathrm{H}_{2}(16.1)+\omega \mathrm{C}_{3} \mathrm{H}_{2}(10.1)$ & $\delta \mathrm{COH}$ \\
\hline 1328 & $\mathrm{~m}$ & 1308 & 43.0 & 1312 & 1.8 & 12.0 & $\mathrm{twC} 4 \mathrm{H}_{2}(36.0)+\gamma \mathrm{NH}_{2}(23.3)$ & twC4 $\mathrm{H}_{2}$ \\
\hline 1240 & vw & 1246 & 8.3 & 1255 & 8.1 & 12.2 & $\mathrm{twC} 2 \mathrm{H}_{2}(36.3)+\mathrm{twC} 3 \mathrm{H}_{2}(27.7)+\mathrm{twC} 4 \mathrm{H}_{2}(13.1)$ & twC2 $2 \mathrm{H}_{2}$ \\
\hline 1211 & vw & 1168 & 2.6 & 1177 & 15.1 & 2.5 & $\mathrm{twC} 3 \mathrm{H}_{2}(25.8)+\gamma \mathrm{C} 4 \mathrm{H}_{2}(15.4)+\gamma \mathrm{NH}_{2}(12.5)$ & twC $3 \mathrm{H}_{2}$ \\
\hline 1108 & $\mathrm{sh}$ & 1118 & 13.1 & 1145 & 10.6 & 3.3 & $\mathrm{twC} 4 \mathrm{H}_{2}(24.4)+\gamma \mathrm{NH}_{2}(17.3)+\operatorname{twC}_{2} \mathrm{H}_{2}(12.6)$ & $\gamma \mathrm{NH}_{2}$ \\
\hline 1073 & s & 1084 & 24.5 & 1084 & 57.9 & 3.2 & $v \mathrm{CO}(28.9)+v \mathrm{CCas} .(26.3)+v \mathrm{CN}(11.3)$ & vCCas. \\
\hline 1054 & s & 1068 & 20.5 & $1060^{\mathrm{c}}$ & 63.5 & 10.3 & $v \mathrm{CO}(38.7)+v \mathrm{CN}(22.0)$ & $v \mathrm{CO}$ \\
\hline 1021 & $\mathrm{sh}$ & 1034 & 13.5 & 1048 & 44.3 & 1.9 & $\delta \mathrm{COH}(20.7)+v \mathrm{CN}(15.7)+\gamma \mathrm{C}_{2} \mathrm{H}_{2}(10.8)$ & $v \mathrm{CN}$ \\
\hline 965 & $\mathrm{~m}$ & 992 & 13.3 & 934 & 15.3 & 3.9 & $\begin{array}{l}v \text { Ccas. }(23.8)+v \mathrm{CN}(16.6)+\gamma \mathrm{C}_{2} \mathrm{H}_{2}(12.9) \\
+\omega \mathrm{NH}_{2}(12.1)\end{array}$ & $\gamma \mathrm{C} 2 \mathrm{H}_{2}$ \\
\hline 910 & $\mathrm{~m}$ & 922 & 27.3 & 902 & 52.4 & 3.2 & $\omega \mathrm{NH}_{2}(37.6)+\gamma \mathrm{C} 2 \mathrm{H}_{2}(14.7)+v \mathrm{CN}(12.6)$ & $\omega \mathrm{NH}_{2}$ \\
\hline 859 & $\mathrm{w}$ & 870 & 16.7 & 870 & 2.5 & 2.5 & $\gamma \mathrm{C} 4 \mathrm{H}_{2}(30.7)+\gamma \mathrm{C} 3 \mathrm{H}_{2}(27.1)+\gamma \mathrm{NH}_{2}(13.1)$ & $\gamma \mathrm{C} 3 \mathrm{H}_{2}$ \\
\hline 823 & $\mathrm{w}$ & 844 & 20.3 & 846 & 73.8 & 2.5 & $\omega \mathrm{NH}_{2}(33.4)+\gamma \mathrm{C} 2 \mathrm{H}_{2}(21.9)+\gamma \mathrm{C} 4 \mathrm{H}_{2}(17.1)$ & $\gamma \mathrm{C} 4 \mathrm{H}_{2}$ \\
\hline 760 & $\mathrm{w}$ & 808 & 9.2 & 771 & 5.9 & 12.0 & $v C C s .(65.3)+\gamma \mathrm{C}^{2} \mathrm{H}_{2}(10.0)$ & $\mathrm{vCCs}$ \\
\hline \multirow[t]{7}{*}{530} & $\mathrm{w}$ & 536 & 12.7 & $239^{\mathrm{c}}$ & 158.9 & 2.5 & $\tau \mathrm{CCNH}(36.3)+\tau \mathrm{HOCC}(34.8)+\delta \mathrm{CCC}(18.1)$ & $\tau \mathrm{HOCC}$ \\
\hline & & & & 490 & 10.8 & 0.4 & $\begin{array}{l}\delta \mathrm{OCC}(25.7)+\gamma \mathrm{C}_{3} \mathrm{H}_{2}(21.8)+\delta \mathrm{CCC}(20.0)+ \\
\delta \mathrm{CCN}(13.8)\end{array}$ & $\delta \mathrm{CCC}$ \\
\hline & & 424 & 19.2 & 400 & 16.7 & 0.3 & $\tau \mathrm{CCNH}(44.3)+\tau \mathrm{HOCC}(40.1)$ & $\tau \mathrm{CCNH}$ \\
\hline & & 390 & 15.6 & 370 & 58.4 & 1.0 & $\delta \mathrm{CCN}(50.2)+\delta \mathrm{OCC}(11.6)$ & $\delta \mathrm{CCN}$ \\
\hline & & 292 & 10.4 & 307 & 10.7 & 0.8 & $\delta \mathrm{OCC}(27.2)+\delta \mathrm{CCC}(26.0)+\tau \mathrm{CCCN}(12.8)$ & $\delta \mathrm{OCC}$ \\
\hline & & & & 145 & 40.1 & 1.1 & $\begin{array}{l}\tau \mathrm{CCCN}(29.7) \tau \mathrm{OCCC}(22.9)+\tau \mathrm{CCNH}(22.9) \\
+\tau \mathrm{HOCC}(21.2)\end{array}$ & $\tau \mathrm{CCCN}$ \\
\hline & & & & 117 & 5.2 & 0.1 & $\tau \mathrm{OCCC}(43.0)+\tau \mathrm{CCCN}(31.9)+\tau \mathrm{CCNH}(13.7)$ & $\tau \mathrm{OCCC}$ \\
\hline
\end{tabular}

\footnotetext{
a Wavenumbers in $\mathrm{cm}^{-1}$; calculated wavenumbers were scaled by 0.89 . Intensities in $\mathrm{km} \mathrm{mol}^{-1}$; infrared experimental intensities $\left(\mathrm{I}^{\mathrm{ir}}\right)$ presented as qualitative relative intensities; Raman experimental intensities are normalised intensities $\left(\mathrm{I}^{\mathrm{R}}\right)$ obtained from the area of each observed peak, subjected to previous deconvolution ( $I_{i}^{\text {obs }}$ ), by using the formula $I^{R}=I_{i}{ }^{\text {obs }} \times \Sigma I_{i}^{\text {cal }} / \Sigma I_{i}^{\text {obs }}\left(\right.$ where $\Sigma I_{i}^{\text {cal }}=\operatorname{sum}$ of the calculated intensities, $\Sigma \mathrm{I}_{\mathrm{i}}^{\text {obs }}=$ sum of the observed intensities, $\mathrm{i}=$ observed band).

${ }^{\mathrm{b}}$ Only Potential Energy Distribution (PED) values larger than $10 \%$ are shown in this table.

${ }^{\mathrm{c}}$ As it is usually observed [20], when the $\mathrm{OH}$ group participates in H-bonding, the wavenumbers of $v \mathrm{OH}$ and $v \mathrm{CO}$ decrease while those of $\delta \mathrm{COH}, \tau \mathrm{HOCC}$ increase relatively to the isolated molecule situation.

${ }^{\mathrm{d}}$ Abbreviations: $v$, stretching; $\delta$, bending; $\gamma$, rocking; $\omega$, wagging; $\tau$, torsion; tw, twisting.
} 

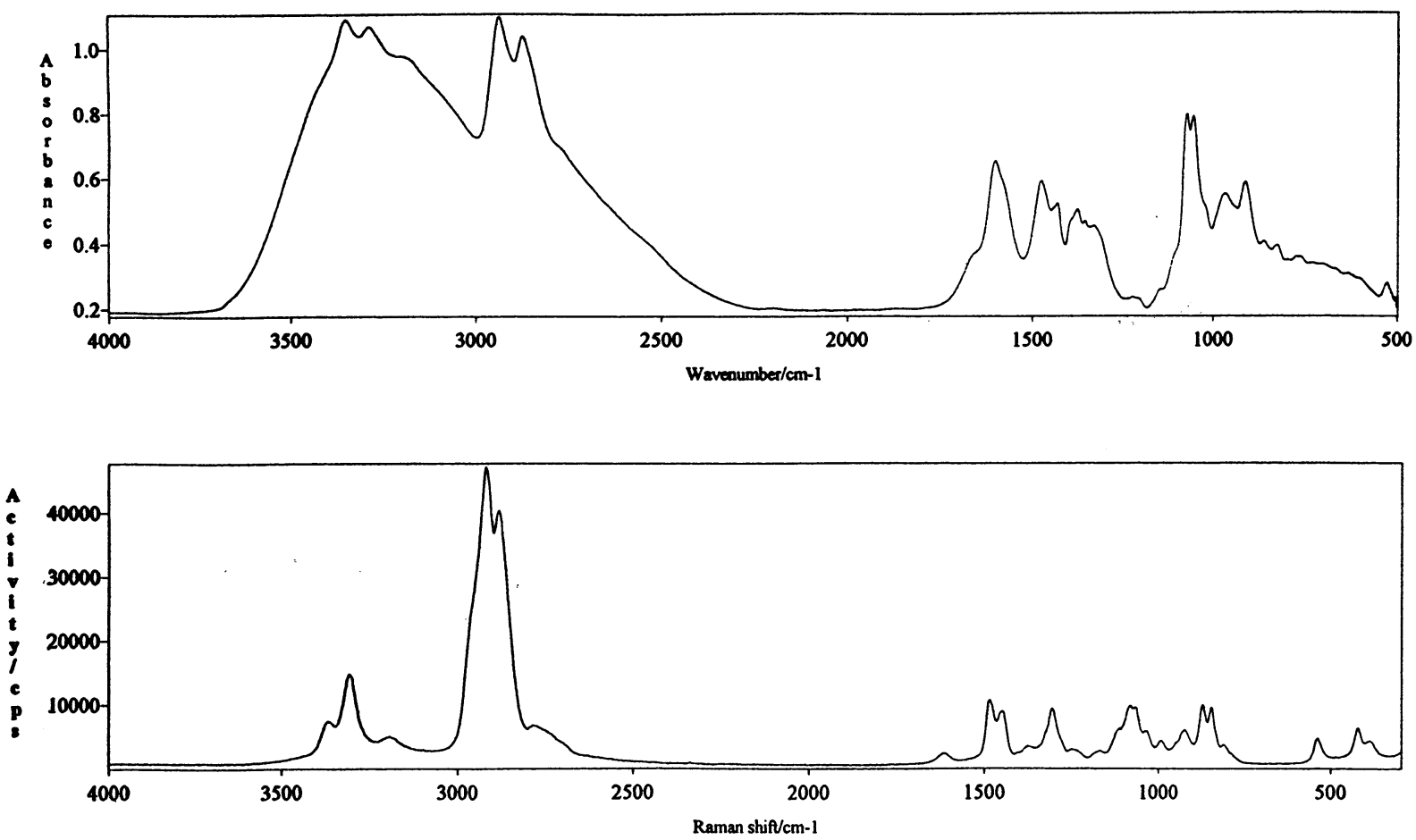

Fig. 7. Liquid phase infrared (upper) and Raman (bottom) spectra of 3-amino-1-propanol (room temperature).

and with the calculated frequencies for this form). In addition, the dependence with temperature of the infrared bands at 1328 and $1054 \mathrm{~cm}^{-1}$ (ascribed to ${ }^{\mathrm{twC}} 4 \mathrm{H}_{2}$ and $v \mathrm{CO}$ of the aggregates), also indicates that these bands must have a partial contribution from vibrational modes of monomeric form I (in particular $\omega \mathrm{C} 3 \mathrm{H}_{2}$ and $v \mathrm{CN}$ ).

The different behavior of $2 \mathrm{AE}$ and $3 \mathrm{AP}$ with respect to the presence of monomeric molecules adopting the conformation I in the liquid phase can be correlated with the fact that the intramolecular $\mathrm{OH}-\mathrm{N}$ hydrogen bond in the conformational ground state of isolated 3AP is much stronger than in isolated 2AE. Indeed, besides the lower observed $\mathrm{vOH}$ frequency for 3AP already mentioned, the calculations also show that form I of $3 \mathrm{AP}$ has a longer $\mathrm{OH}$ bond length and a shorter $\mathrm{N}-\mathrm{HO}$ distance when compared with the corresponding conformer of 2AE (Table 5). Furthermore, a previous theoretical work on aminoalcohols carried out using the $4-31 \mathrm{G}$ basis set also indicated that the strength of the intramolecular $\mathrm{OH}-\mathrm{N}$ interaction in linear aminoalcohols should increase with ring size [5].

The strong intramolecular $\mathrm{OH}-\mathrm{N}$ interaction in 3AP reduces the association tendency in the pure liquid and some monomers of form I are still present in this phase. An increase of temperature leads to an increase of the relative intensities of the bands assigned to this form (Fig. 8), since the ratio between the free and H-bonded species shall increase with temperature (the overall process of complexation is exoenergetic) [21]. A detailed quantitative analysis of this association process,

Table 5

HF 6-31G* calculated $\mathrm{OH}$ bond lengths, N-HO distances for the conformational ground states of 3-amino-1-propanol and 2-aminoethanol for the isolated molecule situation ${ }^{\mathrm{a}}$

\begin{tabular}{lll}
\hline & $\mathrm{r}(\mathrm{OH})$ & $\mathrm{r}(\mathrm{N}-\mathrm{HO})$ \\
\hline 2-aminoethanol & 95.03 & 232 \\
3-amino-1-propanol & 95.15 & 212 \\
\hline
\end{tabular}

\footnotetext{
${ }^{\mathrm{a}}$ Distances in pm.
} 
which is complicated by the change of conformation upon complexation, deserves further attention and studies are actually running in our laboratory to address this question.

\section{Acknowledgements}

The authors acknowledge Dr João Cecílio for his technical help. This work was held within the PRAXIS XXI (QUI/2/2.1/412/94) research programme that is also partially funded by FEDER. Constança Cacela acknowledges the Ph.D. grant (GGPXXI/BD/3873/96) from Fundação para a Ciência e Tecnologia, Lisbon.

\section{References}

[1] C.F.C.P. Silva, M.L.T.S. Duarte, R. Fausto, J. Mol. Struct. 482-483 (1999) 591.

[2] M.A. McMahan, S.D. Sharma, R.F. Curl Jr, J. Mol. Spectrosc. 75 (1979) 220.

[3] M. Przeslawska, S.M. Melikowa, P. Lipkowski, A. Koll, Vibrat. Spectrosc. 20 (1999) 69-83.

[4] A.-M. Kelterer, M. Ramek, J. Mol. Struct. (Theochem) 232 (1991) 189

[5] A.-M. Kelterer, M. Flock, M. Ramek, J. Mol. Struct. (Theochem) 276 (1992) 61.

[6] M. Ramek, M. Flock, A.-M. Kelterer, V.K.W. Cheng, J. Mol. Struct. (Theochem), 267 (1992) 61.
[7] S.T. Mulla, C.I. Jose, J. Chem. Soc. Faraday Trans. I 82 (1986) 707.

[8] P.J. Krueger, H.D. Meettee, Can. J. Chem. 43 (1965) 2970.

[9] Y.-P. Chang, T.-M. su, T.-W. Li, I. Chao, J. Phys. Chem. A101 (1997) 6107.

[10] R.L. Sutton, Chem. Britain 27 (1991) 432.

[11] Microcal software, Microcal origin (Version 4.0), copyright(C) 1991-1995.

[12] K.K. Irikura, SYNSPEC, Physical and Chemical Properties Division National Institute of Standards and Technology, Gaithersburg, MD, 1995.

[13] W.J. Hehre, R. Ditchefield, J.A. Pople, J. Chem. Phys. 56 (1972) 2257.

[14] M.J. Frisch, G.W. Trucks, H.B. Schelegel, P.M.W. Gill, B.G. Johson, M.W. Wong, J.B. Foresman, M.A. Robb, M. Head-Gordon, E.S. Replogle, R. Gomperts, J.L. Andres, K. Raghavachari, J.S. Binkley, C. Gonzalez, R.L. Martin, D.J. Defrees, J. Baker, J.J.P. Stewart, J.A. Pople, GAUSSIAN92/DFT (Revision G.2), Gaussian, Pittsburg, PA, 1993.

[15] H.B. Schlegel, Ph.D. Thesis, Queen's University, Kingston, Ontario, Canada, 1975.

[16] D.J. Defrees, A.D. McLean, J.Chem.Phys. 82 (1985) 333.

[17] M.D.G. Faria, R. Fausto, TRANSFORMER, BUILD-G and VIBRAT (version 1.0), Departamento de Química, Universidade de Coimbra, Portugal, 1990.

[18] M. Räsänen, A. Aspiala, L. Homanen, J. Murto, J. Mol. Struct 96 (1982) 81.

[19] EPA Vapor Phase Library (CAS 156-87-6), Galactic Industries, Salem, NH, 1994.

[20] R. Fausto, J. Mol. Struct. 377 (1996) 181.

[21] G.S.F. D'Alva Torres, C. Pouchan, J.J.C. Teixeira-Dias, R. Fausto, Spectrosc. Lett. 26 (1993) 913. 